\title{
pGVG: a new Gateway-compatible vector for transformation of sugarcane and other monocot crops
}

\author{
Giovanna V. Guidelli ${ }^{1}$, Lucia Mattiello ${ }^{1}$, Rafael H. Gallinari ${ }^{1}$, Paulo Cezar de Lucca ${ }^{2}$ and Marcelo \\ Menossi ${ }^{1}$ D \\ ${ }^{1}$ Laboratório de Genoma Funcional, Universidade Estadual de Campinas, Departamento de Genética, \\ Evolução e Bioagentes, Instituto de Biologia, Campinas, SP, Brazil. \\ ${ }^{2}$ PangeiaBiotech, Universidade Estadual de Campinas, Departamento de Genética, Evolução, Microbiologia \\ e Imunologia, Instituto de Biologia, Campinas, SP, Brazil.
}

\begin{abstract}
The successful development of genetically engineered monocots using Agrobacterium-mediated transformation has created an increasing demand for compatible vectors. We have developed a new expression vector, pGVG, for efficient transformation and expression of different constructs for gene overexpression and silencing in sugarcane. The pCAMBIA2300 binary vector was modified by adding Gateway recombination sites for fast gene transfer between vectors and the maize polyubiquitin promoter Ubi-1 (ZmUbi1), which is known to drive high gene expression levels in monocots. Transformation efficiency using the PGVG vector reached up to 14 transgenic events per gram of transformed callus. Transgenic plants expressing the $\beta$-glucuronidase (GUS) reporter gene from pGVG showed high levels of GUS activity. qRT-PCR evaluations demonstrated success for both overexpression and hairpin-based silencing cassettes. Therefore, pGVG is suitable for plant transformation and subsequent applications for high-throughput production of stable transgenic sugarcane. The use of an expression cassette based on the ZmUbi1 promoter opens the possibility of using PGVG in other monocot species.
\end{abstract}

Keywords: Monocots, sugarcane, vector, Gateway technology, genetic transformation.

Received: August 21, 2017; Accepted: November 27, 2017.

Sugarcane (Saccharum spp L.) is one of the most economically important crops due to its bioenergetic potential and is recognized as a source of renewable energy (Gianotto et al., 2011). Genetic transformation methods are powerful biotechnological tools to improve yield and Agrobacterium-mediated transformation, initially restricted to dicots, has been successfully used in many monocot plants (Gelvin, 2003; Shrawat and Lörz, 2006; Hiei et al., 2014; Slamet-Loedin et al., 2014; Mayavan et $a l ., 2015)$. This method became one of the main approaches used to produce transgenic plants due to its simplicity, low-cost equipment needs and delivery of one or few copies of larger gene insertions. Furthermore the transfer DNA has greater stability, favoring its heritability in comparison to other transformation methods (Elliott et al., 1998; Hansen and Wright, 1999; Travella et al., 2005). Despite that, the availability of vector system compatible for monocots is limited, and most expression vectors are based on the

Send correspondence to Marcelo Menossi. Laboratório Genoma Funcional, Departamento de Genética, Evolução e Bioagentes, Instituto de Biologia, Universidade Estadual de Campinas, CP 6109, 13083-862 Campinas, SP, Brazil. E-mail: menossi@lgf.ib.unicamp.br.
CaMV 35S promoter, which generates lower expression levels in monocots (Mann et al., 2012). There are other vectors for monocot transformation, however they are limited to gene silencing (Karimi et al., 2002), lack epitope tags for protein detection/isolation (Mann et al., 2012), present ZmUbil promoter driving both gene of interest and selection cassettes, which can cause gene silencing (De Wilde et al., 2000; Butaye et al., 2005; Himmelbach et al., 2007; Mann et al., 2012) or show regeneration problems due to the use of hygromycin selection (Joyce et al., 2010).

In this study, we describe the construction and functional validation of a vector ( $\mathrm{pGVG}$ ) for gene functional analysis in sugarcane and other monocots. The $\mathrm{pGVG}$ vector (Figure 1) is based on the backbone from pCAMBIA2300 binary vector (CAMBIA, Canberra, Australia) that possesses the NPTII gene as selection marker. The latter is one of the most efficient markers for transgenic sugarcane callus selection and certified for use in commercial transgenic species (Zhangsun et al., 2007; Joyce et al., 2010). The pGVG vector presents a Gateway cassette (attR1-Cm $\left.{ }^{\mathrm{r}}-c c d \mathrm{~B}-a t t \mathrm{R} 2\right)$ under control of the ZmUbi1 promoter and CaMV 35S terminator for gene overexpression or silencing. By incorporating the Gateway cloning tech- 


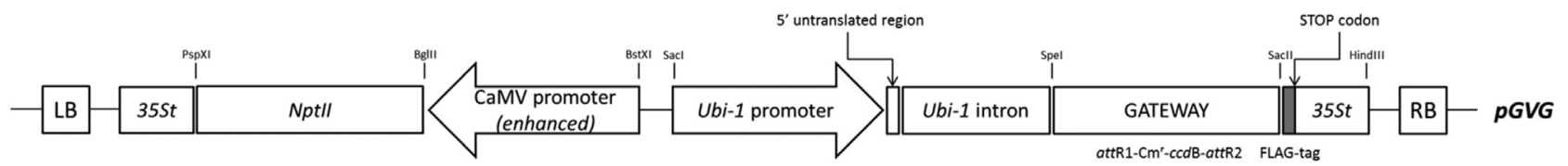

Figure 1 - Schematic structure of the pGVG vector. This vector contains the backbone from pCAMBIA2300, modified by the insertion of the ZmUbil promoter (including 5' untranslated exon and first intron) for strong transgene overexpression and the CaMV $35 \mathrm{~S}$ terminator. The sequences from the Gateway system were inserted between the ZmUBil promoter and the CaMV $35 \mathrm{~S}$ terminator. A FLAG-tag was positioned upstream the terminator to facilitate target protein isolation. The vector also contains the NPTII gene as plant selectable marker under control of the enhanced CaMV $35 \mathrm{~S}$ promoter. $\mathrm{Cm}^{\mathrm{r}}$ : chloramphenicol-resistance gene. $c c d \mathrm{~B}$ : lethal gene. RB: right border. LB: left border.

nology, pGVG allows a fast and easy exchange of DNA fragments between vectors, without using restriction endonucleases and ligases from traditional cloning. Target DNA flanked by att $\mathrm{L}$ recombination sites is easily transferred to att $\mathrm{R}$ site-compatible destination vectors using the LR clonase enzyme. In this process, the lethal $c c d \mathrm{~B}$ gene is moved from the destination plasmid to the entry vector, facilitating the selection of recombinant constructions (Katzen, 2007). Entry vectors such as pCR8GW TOPO (Invitrogen, Life Technologies, USA), with resistance to spectinomycin, are suitable for direct recombination with pGVG. In cases where both entry and pGVG destination vectors have the same bacterial selectable marker it is indicated to use the PCR product flanked by the recombination sites to assure high efficiency of recombination. The $\mathrm{ZmUbil}$ promoter was cloned in pGVG with the 5' untranslated region and the first intron of the Ubi-1 gene, which is associated with enhanced transgene expression in monocot (Callis et al., 1988; Bruce and Quail, 1990; McElroy et al., 1990; Vasil et al., 1993; Christensen and Quail, 1996). This promoter allows high levels of gene expression or RNAi-mediated suppression in most tissue types during most stages of plant development (Cornejo et al., 1993; Mann et al., 2012), and is used to produce stable transgenic monocot plants (Gallo-Meagher and Irvine, 1996; Ma et al., 2000; Kinkema et al., 2014). Additionally, pGVG presents a FLAG-tag sequence (DYKDDDDK) inserted upstream of the CaMV $35 \mathrm{~S}$ terminator for $\mathrm{C}$-terminal fusion with the target protein.

To produce transgenic lines, sugarcane plants (SP80-3280) were cultivated in greenhouse (IAC, Ribeirão Preto, Brazil) for six months, and the meristematic region from shoot apex was used to generate explants. This material was cultivated in MS maintenance medium $[4.33 \mathrm{~g} / \mathrm{L}$ MS salts (Murashige and Skoog, 1962), $1 \mathrm{~mL} / \mathrm{L}$ MS vitamins, $0.15 \mathrm{~g} / \mathrm{L}$ citric acid, $0.5 \mathrm{~g} / \mathrm{L}$ casein hydrolysate, 25 $\mathrm{g} / \mathrm{L}$ sucrose, $12 \mathrm{~g} / \mathrm{L}$ mannitol, $100 \mathrm{mg} / \mathrm{L}$ proline, $3 \mathrm{mg} / \mathrm{L} 2-4$ dichlorophenoxyacetic acid (2,4-D) and $2.8 \mathrm{~g} / \mathrm{L}$ phytagel] at $26{ }^{\circ} \mathrm{C}$ in the dark, until the generation of embryogenic calli. Several constructs based on pGVG (see below) were transferred to Agrobacterium tumefaciens (EHA105 strain) by heat shock. Bacterial cultures were incubated with sugarcane calli under vacuum pressure for $5 \mathrm{~min}$ and transferred to co-cultivation medium $(4.33 \mathrm{~g} / \mathrm{L} \mathrm{MS}$ salts, $1 \mathrm{~mL} / \mathrm{L}$ MS vitamins, $3 \mathrm{mg} / \mathrm{L}$ 2,4-D, $0.15 \mathrm{~g} / \mathrm{L}$ citric acid, $25 \mathrm{~g} / \mathrm{L}$ su- crose and $3.5 \mathrm{~g} / \mathrm{L}$ phytagel) at $22^{\circ} \mathrm{C}$, in the dark for 3 days. Subsequently, the calli were kept in resting medium (4.33 $\mathrm{g} / \mathrm{L}$ MS salts, $1 \mathrm{~mL} / \mathrm{L}$ MS vitamins, $3 \mathrm{mg} / \mathrm{L}$ 2,4-D, $0.5 \mathrm{~g} / \mathrm{L}$ casein hydrolysate, $0.15 \mathrm{~g} / \mathrm{L}$ citric acid, $25 \mathrm{~g} / \mathrm{L}$ sucrose, 100 $\mathrm{mg} / \mathrm{L}$ proline, $2.8 \mathrm{~g} / \mathrm{L}$ phytagel and $200 \mathrm{mg} / \mathrm{mL}$ timentin) at $26^{\circ} \mathrm{C}$, in the dark for 6 days. Following the resting phase, the transformed calli were transferred to a selective regeneration medium $[4.33 \mathrm{~g} / \mathrm{L}$ MS salts, $1 \mathrm{~mL} / \mathrm{L}$ MS vitamins, $25 \mathrm{~g} / \mathrm{L}$ sucrose, $5 \mathrm{mg} / \mathrm{mL} \mathrm{CuSO}_{4}, 1 \mathrm{mg} / \mathrm{mL}$ benzylaminopurine (BAP), $7 \mathrm{~g} / \mathrm{L}$ agar, $200 \mathrm{mg} / \mathrm{mL}$ timentin and 40 $\mathrm{mg} / \mathrm{L}$ geneticin] at $26^{\circ} \mathrm{C}$, during 14 days with $16 \mathrm{~h}$ photoperiod. The transgenic events were kept in medium without phytohormones $(4.33 \mathrm{~g} / \mathrm{L}$ MS salts, $1 \mathrm{~mL} / \mathrm{L}$ MS vitamins, $25 \mathrm{~g} / \mathrm{L}$ sucrose, $7 \mathrm{~g} / \mathrm{L}$ agar, $200 \mathrm{mg} / \mathrm{mL}$ timentin and 40 $\mathrm{mg} / \mathrm{L}$ geneticin) to induce growth and rooting. Plants transformed with pGVG empty vector and wild-type plants were used as negative controls.

The functionality of pGVG was evaluated using the GUS reporter gene. The coding sequence of GUS gene was amplified from the construction pENTR -gus (Invitrogen, Life Technologies, Carlsbad, CA), using specific primers designed in the at $t \mathrm{~L}$ Gateway recombination sites. The purified PCR product was recombined with pGVG using Gateway ${ }^{\circledR}$ LR Clonase ${ }^{\circledR}$ II enzyme (Invitrogen, Life Technologies). The resulting vector was introduced into Agrobacterium and used for calli transformation. Transgene expression was assessed by GUS histochemical staining (Jefferson, 1987). Strong GUS activity was detected in callus and whole plants (Figure 2), confirming that pGVG is suitable for sugarcane transformation.

To further evaluate the transformation capacity of pGVG, sugarcane genes related with different biological processes were tested using overexpression and RNAimediated silencing constructs (Table 1). The vector was able to transform sugarcane plants with genes of different sizes for both construct types. The overall transformation efficiency showed variation, probably reflecting differences in callus quality, culture medium, age and selective subculturing, which affect both transformation and plant regeneration (Pacurar et al., 2008; Basnayake et al., 2011).

Analyses of gene expression were performed through qRT-PCR using gene-specific primers and the polyubiquitin gene (SCCCST2001G02.g) as internal control for normalization (Papini-Terzi et al., 2005) (Figure 3). The results demonstrated that sugarcane genes 1 and 2 were up- 

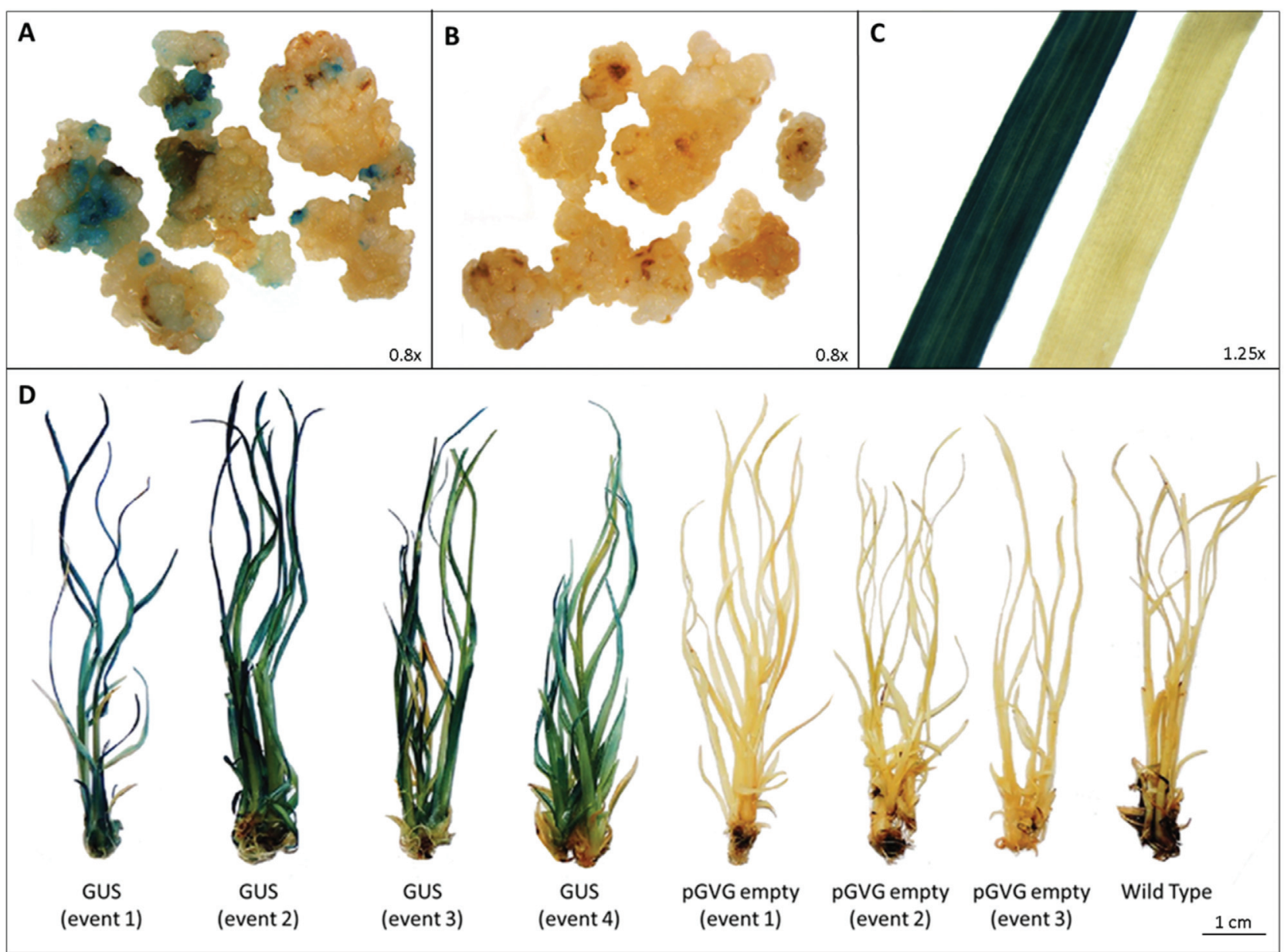

Figure 2 - GUS expression on transgenic sugarcane tissues obtained from Agrobacterium-mediated transformation system using the pGVG vector. Transformed (A) and untransformed (B) calli, three weeks after the co-culture period; (C) leaves from a transformed (left) and untransformed (right) plant; (D) transformed (GUS, pGVG empty) and untransformed (Wild Type) plants, 4 months after the co-culture period.

Table 1 - Transformation efficiency in sugarcane using pGVG.

\begin{tabular}{|c|c|c|c|c|c|}
\hline Gene function & Type of cassette & Events & Callus $(\mathrm{g})$ & Efficiency $^{\mathrm{b}}$ & Construct size (bp) \\
\hline Gene 1 - Drought stress & $\mathrm{OE}$ & 153 & 15 & 10.20 & 573 \\
\hline Gene 2 - Drought stress & $\mathrm{OE}$ & 215 & 15 & 14.33 & 1,185 \\
\hline Gene 3 - Drought stress & $\mathrm{OE}$ & 142 & 15 & 9.46 & 384 \\
\hline Gene 4 - Drought stress & OE & 71 & 15 & 4.73 & 453 \\
\hline Gene 5 - Drought stress & $\mathrm{OE}$ & 85 & 10 & 8.50 & 243 \\
\hline Gene 6 - Drought stress & OE & 59 & 10 & 5.90 & 849 \\
\hline Gene 7 - Drought stress & $\mathrm{OE}$ & 125 & 10 & 12.50 & 942 \\
\hline Gene 8 - Drought stress & $\mathrm{OE}$ & 89 & 10 & 8.90 & 609 \\
\hline Gene 9 - Growth & $\mathrm{OE}$ & 75 & 10 & 7.50 & 1,086 \\
\hline Genes 9, 10 and 11 - Growth & HS & 71 & 10 & 7.10 & 892 \\
\hline Gene 9 - Growth & HS & 84 & 10 & 8.40 & 632 \\
\hline Gene 12 - Cell wall biosynthesis & HS & 42 & 15 & 2.80 & 1,125 \\
\hline Gene 13 - Cell wall biosynthesis & HS & 129 & 15 & 8.60 & 923 \\
\hline Gene 14 - Cell wall biosynthesis & HS & 182 & 15 & 12.13 & 605 \\
\hline Genes 15,16 and 17 - Development & HS & 24 & 15 & 1.60 & 2,795 \\
\hline Genes 15 and 16 - Development & HS & 80 & 10 & 8.00 & 1,314 \\
\hline pGVG & Empty vector & 30 & 7 & 4.29 & 1,455 \\
\hline pGVG & Empty vector & 6 & 5 & 1.20 & 1,455 \\
\hline pGVG & Empty vector & 15 & 7 & 2.14 & 1,455 \\
\hline
\end{tabular}

${ }^{\mathrm{a}} \mathrm{OE}$ : overexpression, HS: hairpin silencing; ${ }^{\mathrm{b}}$ Transformation efficiency expressed as the number of transgenic plants per gram of fresh callus matter. 
A
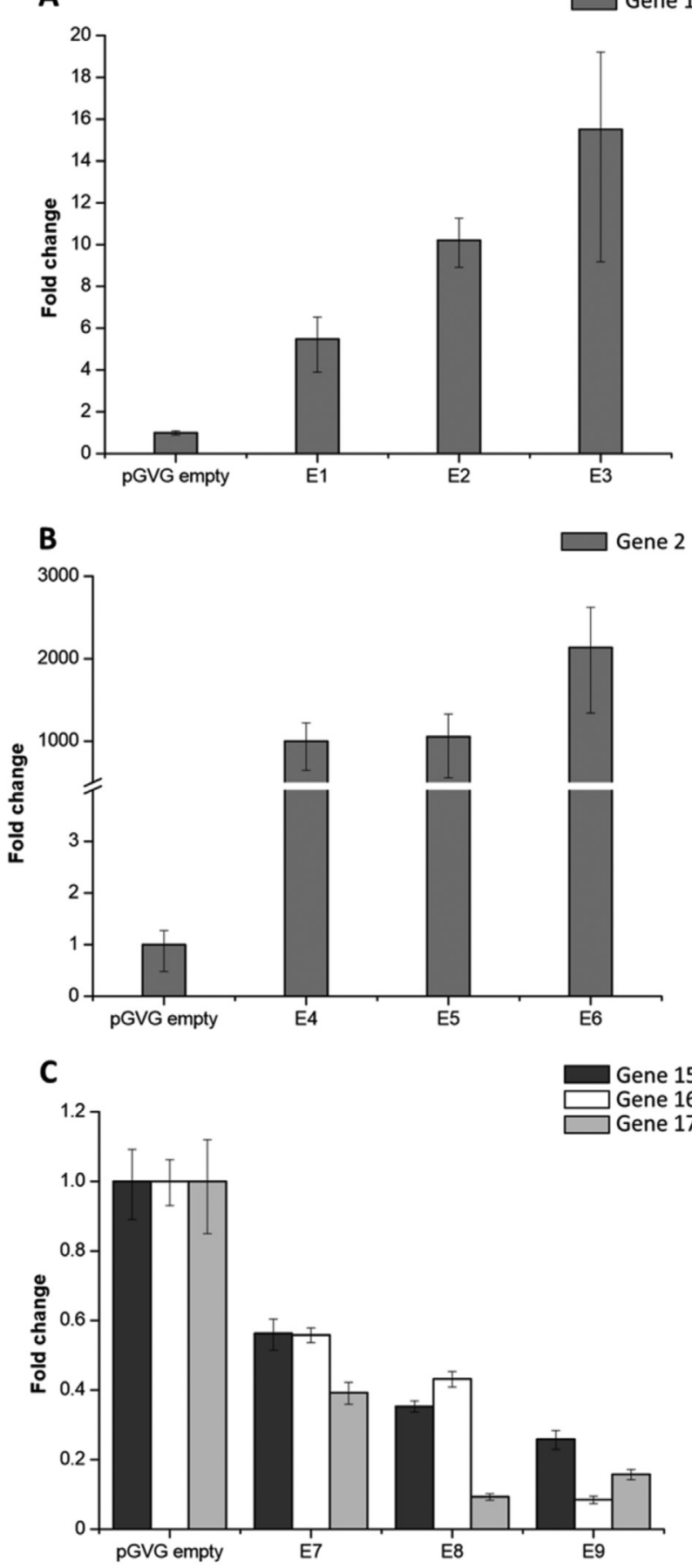

Figure 3 - Expression levels of different sugarcane genes induced or repressed in transgenic sugarcane plants using the pGVG vector. Leaves from transgenic plants were used to extract RNA and the transcripts were quantified using RT-qPCR (A) Overexpression of gene 1 (drought stressrelated) in three independent lines (E1, E2, and E3) compared with control (pGVG empty). (B) Overexpression of gene 2 (drought stress-related) in three independent lines (E4, E5 and E6) compared with control (pGVG empty). (C) RNAi-mediated suppression of the genes 15, 16 and 17 (development related; triple silencing) in three independent lines (E7, E8 and E9) compared with control (pGVG empty). Data represent the mean of three biological replicates. Bars indicate the standard error. The expression data refer to the transgene and the correspondent endogenous gene levels. The genes named here are the same as described in Table 1. regulated in different levels in the transgenic lines when compared with endogenous levels observed in the empty vector control (Figure 3A,B). Additionally, a unique hairpin construction that targets three genes of the same family (genes 15, 16 and 17) silenced each member reaching up to $92 \%$ of down-regulation (Figure $3 \mathrm{C}$ ). These data show that pGVG is able to produce efficient transgene overexpression and suppression of target genes.

Therefore, the combination of adequate plant selectable markers, Gateway technology, and stable and strong promoters in the pGVG vector assures effective transformation and plant regeneration demonstrated by GUS reporter gene expression and qRT-PCR assays. This vector can be used in overexpression and RNAi-mediated silencing of sequences of interest in sugarcane plants that will greatly facilitate the functional characterization of genes. All characteristics incorporated into pGVG certainly will allow it to be used successful in several other monocot species.

\section{Acknowledgments}

This work was supported by Fundação de Amparo à Pesquisa do Estado de São Paulo (FAPESP) to MM (grant 2013/15576-5), GVG (grant 2014/26521-0), LM (grant 2015/23789-4) and PCL (grant 2015/08659-7).

\section{References}

Basnayake SW, Moyle R and Birch RG (2011) Embryogenic callus proliferation and regeneration conditions for genetic transformation of diverse sugarcane cultivars. Plant Cell Reports 30:439-448.

Bruce WB and Quail PH (1990) cis-acting elements involved in photoregulation of an oat phytochrome promoter in rice. Plant Cell 11:1081-1089.

Butaye KMJ, Cammue BPA, Delaure SL and de Bolle MFC (2005) Approaches to minimize variation of transgene expression in plants. Mol Breed 16:79-91.

Callis J, Fromm M and Walbot V (1988) Heat inducible expression of a chimeric maize hsp70CAT gene in maize protoplasts. Plant Physiol 88:965-968.

Christensen AH and Quail PH (1996) Ubiquitin promoter-based vectors for high-level expression of selectable and/or screenable marker genes in monocotyledonous plants. Transgenic Res 5:213-218.

Cornejo MJ, Luth D, Blankenship KM, Anderson OD and Blechl AE (1993) Activity of a maize ubiquitin promoter in transgenic rice. Plant Mol Biol 23:567-581.

De Wilde C, Van Houdt H, De Buck S, Angenon G, De Jaeger G and Depicker A (2000) Plants as bioreactors for protein production: avoiding the problem of transgene silencing. Plant Mol Biol 43:347-359.

Elliott AR, Campbell JA, Brettell RIS and Grof CPL (1998) Agrobacterium-mediated transformation of sugarcane using GFP as a screenable marker. Functional Plant Biol 25:739-743. 
Gallo-Meagher M and Irvine JE (1996) Herbicide resistant transgenic sugarcane plants containing the bar gene. Crop Sci 36:1367-1374.

Gelvin, SB (2003) Agrobacterium-mediated plant transformation: The biology behind the "gene-jockeying" tool. Microbiol Mol Rev 67:16-37.

Gianotto AC, Abreu HMC, Arruda P, Bespalhok JCF, Burnquist WL, Creste S, Ciero L, Ferro JA, Figueira AVO and Filgueiras TS (2011) Sugarcane (Saccharum X officinarum): A reference study for the regulation of genetically modified cultivars in Brazil. Trop Plant Biol 4:62-89.

Hansen G and Wright MS (1999) Recent advances in the transformation of plants. Trends Plant Sci 4:226-231.

Hiei Y, Ishida Y and Komari T (2014) Progress of cereal transformation technology mediated by Agrobacterium tumefaciens. Frontiers Plant Sci 5:1-11.

Himmelbach A, Zierold U, Hensel G, Riechen J, Douchkov D, Schweizer P and Kumlehn J (2007) A set of modular binary vectors for transformation of cereals. Plant Physiol 145:1192-1200.

Jefferson R (1987) Assaying chimeric genes in plants: The GUS gene fusion system. Plant Mol Biol Rep 5:387-405.

Joyce P, Kuwahata M, Turner N and Lakshmanan P (2010) Selection system and co-cultivation medium are important determinants of Agrobacterium-mediated transformation of sugarcane. Plant Cell Rep 29:173-183.

Karimi M, Inzé D and Depicker A (2002) GATEWAY vectors for Agrobacterium-mediated plant transformation. Trends Plant Sci 7:193-195.

Katzen F (2007) Gateway ${ }^{\circledR}$ recombinational cloning: A biological operating system. Expert Opin Drug Discov 2:571-589.

Kinkema M,Geijskes J,deLucca P,Palupe A,Shand K,Coleman H,Brinin A,Williams B,Sainz M and Dale J (2014)Improved molecular tools for sugar cane biotechnology.Plant Mol Biol84:497-508.

Ma H, Albert H, Paull R and Moore P (2000) Metabolic engineering of invertase activities in different subcellular compartments affects sucrose accumulation in sugarcane cells. Aust J Plant Physiol 27:1021-1030.

Mann DGJ, LaFayette PR, Abercombrie LL, King ZR, Mazarei M, Halter MC, Poovaiah CR, Baxter H, Shen H, Dixon RA et al. (2012) Gateway-compatible vectors for highthroughput gene functional analysis in switchgrass
(Panicum virgatum L.) and other monocot species. Plant Biotechnol J 10:226-236.

Mayavan S, Subramanyam K, Jaganath B, Sathish D, Manickavasagam $M$ and Ganapathi A. (2015) Agrobacteriummediated in planta genetic transformation of sugarcane setts. Plant Cell Rep 34:1835-1848.

McElroy D, Zhang W, Cao J and Wu R (1990) lsolation of an efficient actin promoter for use in rice transformation. Plant Cell 2:163-171.

Murashige T and Skoog F (1962) A revised medium for rapid growth and bioassays with tobacco tissue cultures. Physiol Plant 15:473-497.

Pacurar DI, Thordal-Christensen H, Nielsen KK and Lenk I (2008) A high-throughput Agrobacterium-mediated transformation system for the grass model species Brachypodium distachyon L. Transgenic Res 17:965-975.

Papini-Terzi FS, Rocha FR, Vêncio RZ, Oliveira KC, Felix JM, Vicentini R, Rocha CS, Simões AC, Ulian EC, di Mauro SMZ et al. (2005) Transcription profiling of signal transduction-related genes in sugarcane tissues. DNA Res 12:27-38.

Shrawat AK and Lörz H (2006) Agrobacterium-mediated transformation of cereals: A promising approach crossing barriers. Plant Biotechnol J 4:575-603.

Slamet-Loedin IH, Chadha-Mohanty P and Torrizo L (2014) Agrobacterium-mediated transformation: rice transformation. Methods Mol Biol 1099:261-271.

Travella S, Ross SM, Harden J, Everett C, Snape JW and Harwood WA (2005) A comparison of transgenic barley lines produced by particle bombardment and Agrobacteriummediated techniques. Plant Cell Rep 23:780-789.

Vasil V, Srivastava V, Castillo AM, Fromm ME and Vasil IK (1993) Rapid production of transgenic wheat plants by direct bombardment of cultured immature embryos. Biol Technol 11:1553-1558.

Zhangsun D, Luo S, Chen R and Tang K (2007) Improved Agrobacterium-mediated genetic transformation of GNA transgenic sugarcane. Biologia 62:386-393.

Associate Editor: Marcia Pinheiro Margis

License information: This is an open-access article distributed under the terms of the Creative Commons Attribution License (type CC-BY), which permits unrestricted use, distribution and reproduction in any medium, provided the original article is properly cited. 